\title{
Jurnal Ilmiah Manajemen
}

\section{AT T TADBIR}

VOL 4, No. 2 Juli 2020

Bagaimana Iklim Etis Dan Gaya Kepemimpinan Berpengaruh

Terhadap Efektifitas Pemimpin?

Iqbal robbie, Ardik Praharjo 181 - 90

Consumer Preferences of Halal-Friendly Hotel Attributes

Fadhila Azhari Shafa 191 - 101

Reaksi Pasar Modal Indonesia Sebelum dan Sesudah Pengumuman Paket Kebijakan Ekonomi XVI pada Saham Sektor Pertambangan yang Terdaftar Di Bursa Efek Indonesia Tahun 2018

Erni Alfisah | $102-113$

Pengaruh Motivasi Kerja Dan Kompetensi Terhadap Kinerja Karyawan Yayasan Bina Insan Nusantara Barito Di Buntok, Provinsi Kalimantan Tengah Agustina Muliyani । $114-129$

Pengaruh Kepedulian, Pengetahuan, Sikap, Inisiatif Pemerintah, Tekanan Teman Sebaya Dan Spiritualitas Terhadap Niat Beli

Produk Ramah Lingkungan Di Banjarmasin

Arafat Alhally | $130-142$

Pengaruh Pengawasan Dan Disiplin Kerja Terhadap Produktivitas Karyawan PT. Kideco Jaya Agung Kecamatan Batu Sopang Shalahuddin, Danang Alfian Saputra, Dedy Darmawan | 143 - 151

Pengaruh Strategi Promosi Dan Harga Terhadap Keputusan Pembelian Yang Dimediasi Oleh Minat Beli Kain Sasirangan Bordir Periyadi, Junaidi, Noorlaily Maulida | 152 - 162 


\title{
AT T TADBIR |At-Tadbir: \\ $\mathrm{AT} \sim \mathrm{TADBIR}$ |jurnal ilmiah manajemen
}

\author{
Ketua Editorial \\ Dr. Dwi Wahyu Artiningsih. MM.
}

\section{Tim Editorial}

Irma Yusnita, SE, MM, Universitas Islam Kalimantan MAB Banjarmasin

Zakky Zamrudi, SAB., MAB, Universitas Islam Kalimantan MAB Banjarmasin

Ardik Praharjo, SAB, MAB, Universitas Muhammadiyah Malang

Moh. Amin Rosidi, SE, MM, Universitas Khairun, Ternate

Fanlia Adiprimadana Sanjaya, Universtias Islam Kalimantan

\section{Mitra Bestari}

Dr. Bactiar Yanuar, Sekolah Tinggi Ilmu Ekonomi Indonesia - Banjarmasin, Indonesia

I Gede Eko Putra Sri Sentanu, Ph.D, Universitas Brawijaya, Malang

Dr. Rahmi Widyanti, Universitas Islam Kalimantan MAB Banjarmasin

Dr. Jauhar Arifin, Sekolah Tinggi Ilmu Administrasi Amuntai

Dr. sulastini sulastini, Universitas Islam Kalimantan MAB Banjarmasin

Dr. Hairudinor Hairudinor, Universitas Lambung Mangkurat

\section{ALAMAT REDAKSI :}

Program Pascasarjana Universitas Islam Kalimantan Muhammad Arsyad Al-Banjari Banjarmasin

Jl. Adhyaksa No. 02 Kayutangi Banjarmasin, G.B.L1,

Kalimantan Selatan

Tlp. (0511) 3306170 Fax. (0511) 3303872

Email : jurnal.attadbir@gmail.com

Website : https://ojs.uniska-bjm.ac.id/index.php/jurnalattadbir/index

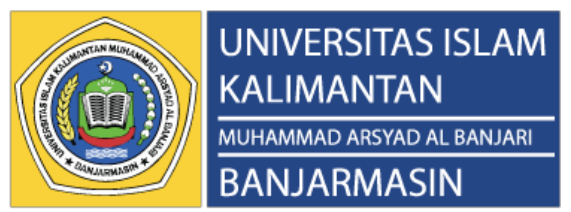


Dengan mengucap syukur kepada Allah SWT, At-Tadbir: Jurnal Ilmiah Manajemen Uniska telah dapat menerbitkan terbitan ilmiah berkala di bidang manajemen, Volume 4 Nomor 2, Juli 2020. Terbitan ini memuat tulisan-tulisan dari penulis yang berasal dari berbagai insitusi di Indonesia.

Jurnal At-Tadbir adalah media informasi yang merupakan media yang memfasilitasi tulisan-tulisan ilmiah dibidang ilmu manajemen baik berupa penelitian dosen, mahasiswa, maupun peneliti di bidang manajemen maupun hasil kajian dalam bidang ekonomi yang diterbitkan dengan masa terbitan dua kali dalam setahun yaitu pada bulan Januari dan Juli.

Kepada semua pihak, terutama penulis yang berkontribusi pada Jurnal AtTadbir: Jurnal Ilmiah Manajemen, Volume 4 Nomor 2, Juli 2020, Rektor Uniska, Dekan Fakultas Ekonomi Uniska, Direktur Program Pascasarjana, dan terutama Tim Editorial dan semua pihak yang tidak bisa disebutkan satu persatu Tim Editorial mengucapkan terimakasih. 


\section{AT TADBIR |At:-iadibie}

1. Bagaimana Iklim Etis Dan Gaya Kepemimpinan Berpengaruh

Terhadap Efektifitas Pemimpin?

Iqbal robbie, Ardik Praharjo

2. Consumer Preferences of Halal-Friendly Hotel Attributes

Fadhila Azhari Shafa

3. Reaksi Pasar Modal Indonesia Sebelum dan Sesudah Pengumuman

$102-113$

Paket Kebijakan Ekonomi XVI pada Saham Sektor Pertambangan

yang Terdaftar Di Bursa Efek Indonesia Tahun 2018

Erni Alfisah

4. Pengaruh Motivasi Kerja Dan Kompetensi Terhadap Kinerja

Karyawan Yayasan Bina Insan Nusantara Barito Di Buntok, Provinsi

Kalimantan Tengah

Agustina Muliyani

5. Pengaruh Kepedulian, Pengetahuan, Sikap, Inisiatif Pemerintah,

Tekanan Teman Sebaya Dan Spiritualitas Terhadap Niat Beli Produk

Ramah Lingkungan Di Banjarmasin

Arafat Alhally

6. Pengaruh Pengawasan Dan Disiplin Kerja Terhadap Produktivitas

Karyawan PT. Kideco Jaya Agung Kecamatan Batu Sopang

Shalahuddin, Danang Alfian Saputra, Dedy Darmawan

7. Pengaruh Strategi Promosi Dan Harga Terhadap Keputusan

$152-162$

Pembelian Yang Dimediasi Oleh Minat Beli Kain Sasirangan Bordir

Periyadi, Junaidi, Noorlaily Maulida 